\title{
The Rise of Institutional Investors ${ }^{1}$
}

\author{
Jan Fichtner
}

CORPNET Project, University of Amsterdam

\begin{abstract}
During the last decades, institutional investors gained an ever more important position as managers of assets and owners of corporations. By demanding (short-term) shareholder value, some of them have driven the financialization of corporations and of the financial sector itself. This chapter first characterizes the specific roles that private equity funds, hedge funds, and mutual funds have played in this development. It then moves on to focus on one group of institutional investors that is rapidly becoming a pivotal factor for corporate control in many countries - the "Big Three" large passive asset managers BlackRock, Vanguard and State Street.
\end{abstract}

\section{Acknowledgements}

Gerald Epstein, Philip Mader and Natascha van der Zwan provided very helpful comments on earlier versions of this chapter.

\footnotetext{
${ }^{1}$ This is the pre-print version of a chapter in the forthcoming "International Handbook of Financialization" (Routledge), edited by Philip Mader, Daniel Mertens, and Natascha van der Zwan.
} 


\section{Introduction}

Since the 1980s, institutional investors have increased their assets under management enormously. This trend has been driven both by rapidly growing equity markets and by the fact that households increasingly shifted from direct stock ownership to holdings via asset managers. Moreover, institutional investors benefited from the development that many countries changed their pension systems from "defined benefit" to "defined contribution" schemes that involve investment via asset managers (Rutterford and Hannah, 2016). Through these developments, institutional investors have become large owners of publicly listed corporations in virtually all countries that have developed equity markets. This chapter focuses on how institutional investors have shaped and driven the financialization of listed companies and the financial sector itself, primarily by demanding the maximization of shortterm shareholder value. The main measures to increase shareholder value have included share buybacks and special dividends as well as mergers. Additionally, many institutional investors have pushed for an alignment of (short-term) interests between managers and shareholders through stock-based forms of remuneration, thus reinforcing the financialization of listed corporations.

In this chapter, we understand the financialization of listed corporations as a process in which companies increasingly focus their strategic thinking exclusively on financial matters, such as the short-term maximization of profits and techniques of financial engineering which help reaching that goal (see also Erturk, 2019, in this volume). Such finance-driven firm strategies necessarily are often detrimental to the interests of stakeholders such as workers and suppliers, and may increase the risks for the economy at large through higher corporate debt loads. Potential consequences that the financialization of listed companies may entail include reduced investment in long-term research and development, reduced competition between firms in concentrated markets, extremely elevated levels of executive compensation, and thus increased economic inequality and lower economic growth (Horn, 2017). This chapter seeks to contribute to exposing the (frequently hidden) power relations that underlie and drive the process of corporate financialization in many countries, and show how these relations have changed over time. Therefore, this chapter begins with a brief overview of the emergence of institutional investors and of equity markets in general as the former are inextricably linked to the latter. This is followed by a characterization of the specific roles that private equity funds, hedge funds, and mutual funds have played in corporate financialization. Hedge funds and private equity funds can be classified as the high fee segment of the asset management industry, while mutual funds arguably constitute the medium fee segment. Subsequently, the focus shifts on the rapidly growing low fee segment, which consists of passive index funds. In contrast to the fragmented mutual fund and hedge fund industries, the burgeoning index fund industry is heavily concentrated in the hands of what Fichtner, Heemskerk and GarciaBernardo (2017) call the "Big Three." BlackRock, Vanguard and State Street form this small group of giant US passive asset managers, which is rapidly becoming a pivotal force for 
corporate control in many countries. Therefore, the "Big Three" represent a crucial factor for the financialization (but potentially also the de-financialization) of listed corporations.

\section{Emergence and overview of institutional investors}

Many precursors of modern financial markets were developed in the Netherlands. In the $17^{\text {th }}$ century, the Dutch East India Company became the first company to list shares on a public stock market. Such a public listing on the stock market enabled the corporation to raise capital from many different private investors, which could subsequently be utilized to finance risky but also very lucrative business endeavors overseas. Besides being arguably the first major transnational corporation in history, the Dutch East India Company pioneered modern corporate governance. In 1622, there was even the first case of what might today be called "shareholder activism" when one investor voiced his discontent about how the company was run (De Jongh, 2011). The development of public stock markets enabled companies to raise capital on a large scale through the issuance of shares and thus created an additional instrument to corporate bonds (see Petry, 2019, in this volume, on exchanges and financialization). Thus, since that time the primary beneficial function of stock markets for the economy as a whole was to channel money from investors to companies that used it to fund their activities (see also Beck and Knafo, 2019, in this volume, on the uses of history).

Arguably the first modern mutual funds were created in the late 1920s in Boston when companies such as State Street and Wellington offered open-end funds that for the first time enabled the continuous issuance and redemption of shares. This made them accessible to a much wider range of investors. These actively managed mutual funds could invest both in stocks and bonds. The United States enacted key pieces of regulation for mutual funds and other investment instruments during the 1930s and 1940s, which inter alia created the Securities and Exchange Commission (SEC). These measures subsequently enabled the emergence of institutional investors during the 1950s and 1960s, when also both private equity and hedge funds began to emerge in embryonic form. In the 1970s, Vanguard created the first index fund, a new concept where the fund manager is not actively selecting different stocks in order to maximize returns. Instead, the fund simply replicates established stock indices, such as the S\&P 500 (which comprises the largest listed US corporations), and keeps costs low. The aim of this original index fund was to enable retail investors for the first time to achieve a diversified yet also cost-efficient investment in equities (Bogle, 2016). Thus, by the late 1970s almost all major kinds of contemporary institutional investors had been developed.

Institutional investors can have different legal forms and follow diverse investment strategies, what they have in common is that they are "intermediary investors" - they are institutions that manage other people's money (Kay, 2016). During the 1970s, institutional investors were still quite small in absolute and relative terms. For example, institutional investors only held 
less than 20 percent of total outstanding stock by listed companies in the United States in the early 1970s (Useem, 1996). It was during the 1980s and 1990s when financial markets started to grow enormously in many countries and transnational financial flows developed rapidly that institutional investors began their real rise to become the pivotal financial actors they are today.

In 2016, the top 500 global asset managers together had US\$81.2 trillion in assets under management, which is slightly more than global GDP. The top 20 asset managers account for over 42 percent of this enormous figure. Asset managers from the United States dominate the top 500 and manage over 53 percent of total global assets. The second largest country is the UK with British asset managers accounting for almost 8 percent of global assets, while France on place three accounts for about 7 percent. Germany and Canada complete the top five, accounting for six, respectively five percent of total assets (WillisTowersWatson, 2017).

For the purposes of this chapter, it is instructive to analytically separate the asset management industry into three different segments of institutional investors: a high fee segment consisting of private equity and hedge funds, a medium fee segment comprised of traditional actively managed mutual funds, and the relatively new burgeoning segment of passive index funds. The institutional investors of each segment play different roles for the financialization of publicly listed corporations, thus it makes sense to discuss them separately. The medium fee segment comes first, because for many decades mutual funds had been the by far dominant form of institutional investor. Therefore they are often referred to as "traditional" asset managers, whereas hedge funds and private equity funds, which grew later, are frequently labeled "alternative" asset managers.

\section{The medium fee segment: actively managed mutual funds}

As mentioned above, mutual funds first developed in the 1920s in the United States. The main reason why they became so successful was that private individuals could for the first time invest with ease even relatively small amounts of money in a diversified portfolio of stocks (and/or bonds). Mutual funds have grown significantly from the 1950s to the 1970s, albeit from a small base. Their real take-off happened during the 1970s and 1980s. One crucial development was the introduction of so-called " $401(k)$ " pension plans in the United States in the early 1980s, through which individuals could invest a part of their salary in a very taxefficient way. Mutual funds were the main recipients of these investments (often via pension funds). The rise of defined contribution pension plans, therefore, fueled the growth of actively managed mutual funds.

Concurrently to this beginning boost of mutual funds, the SEC instituted a new rule in 1982, which enabled the development of a major mechanism for the financialization of listed corporations - share buybacks, which before had been considered as market manipulation. 
The deregulation-minded President Reagan had appointed the first Wall Street executive as head of the SEC since the 1930s, John Shad. Shad reportedly believed that allowing share buybacks would lead to increases in stock prices, and thus be beneficial to shareholders (Lazonick, 2015). The main intended effect of share buybacks is that they reduce the number of outstanding (i.e. publicly traded) shares. This improves a range of financial firm ratios that have been advocated by proponents of shareholder value maximization, such as earnings per share (EPS). Repurchased shares are either canceled or kept as treasury shares (with the main aim to use them for mergers and acquisitions and/or for stock-based executive remuneration).

As such, share-buybacks constitute pure short-term financial engineering to increase the share price; they have no effect on revenues or total profits. However, they reduce the amount of funds that are available for long-term research and development and other kinds of investment. Moreover, a problematic aspect is that coupled with stock options, which became more widely used during the 1960s and 1970s, share buybacks can cause management to pursue purely financial aims at the expense of prioritizing long-term strategies including research and development. When the exercise of stock options is tied to the attainment of specific EPS values, this clearly can be seen as a financialized moral hazard problem for management.

Lazonick has convincingly argued that the rise of the "maximizing shareholder value" ideology in the mid-1980s has led to a paradigm shift of publicly listed corporations from a model of "retain-and-reinvest" to "downsize-and-distribute" (Lazonick, 2015; see also Lazonick and O'Sullivan, 2000). In the retain-and-reinvest model, corporations seek to retain earnings and reinvest them in productive capacities. Corporations adhering to the downsize-and-distribute paradigm primarily distribute corporate cash to shareholders while cutting expenses for investment and labor. According to Lazonick, the ascent of the "buyback corporation" is mainly responsible for many of the negative effects often ascribed to financialization, such as drastically increased income inequity, heightened employment instability, and reduced innovative capabilities of many firms (see also Davis, 2008).

The volume of buybacks in the United States alone is staggering. From 2004 to end-2015, the companies of the S\&P 500 have spent more than US\$4.5 trillion for repurchasing their own shares. ${ }^{2}$ This has led to the situation that the US stock market has completely changed its function during the last three decades, turning from an institution that brings capital from investors to firms that use it for investment into a mechanism that channels funds out of listed firms to investors. Remarkably, from 2000 to 2017 the US stock market facilitated negative net equity issuance of almost US\$5.4 trillion! $!^{3}$ In other words, the US stock market has been utilized to channel capital out of corporations on an unprecedented scale. We know that the top one percent in the United States own approximately 40 percent of total stock market

\footnotetext{
${ }^{2}$ Calculations by the author based on Lazonick (2015) and FactSet (2016).

${ }^{3}$ Gross equity issuance minus retirements (stock repurchases as well as mergers and acquisitions); author's calculations based on Federal Reserve (2017).
} 
wealth - while the top ten percent even own about 80 percent (Wolff, 2014; see also Godechot, 2019, in this volume). Hence, we can conclude that the American stock market has become a giant device that extracts capital from listed corporations to distribute it to capitalowners. Mutual funds have been generally supportive of the increased use of share buybacks and the growing trend of mergers and acquisitions, which actually often diminish the value of the amalgamated corporation, inter alia due to high fees paid to investment banks and law firms.

Writing in the mid-1990s, Michael Useem coined the term "investor capitalism" to characterize the ascent of institutional investors that happened in the previous decades. The prior period, which he calls "managerial capitalism" was marked by the dominance of management, as the ownership of most listed US corporations was dispersed - the famous separation of ownership and control described by Berle and Means in 1932. According to Useem (1996: 207), the rise of institutional investors led to a rebalancing of power between shareholders and management - "negotiated relations between co-equals."

A decade later, Davis (2008) introduced the term "new finance capitalism." Davis found that by 2005 mutual funds had accumulated five percent blockholdings in hundreds of US companies. Being the single largest shareholder gave the biggest mutual funds - such as his running example Fidelity - power over the corporate governance of these companies by means of dominating corporate elections. However, he found that the large mutual fund groups preferred to sell their shares ("exit") rather than to exert direct influence ("voice") over the corporate governance of their investee firms. Thus, Davis (2008: 13) concluded that "networks of concentrated yet liquid ownership without control seem to be the distinctive feature of the new finance capitalism." During the 2000s, it became more common to refer to mutual funds as "traditional" asset managers. In contrast to this supposedly conventional way of asset management, private equity and hedge funds portrayed themselves as "alternative" investors.

\section{The high fee segment: private equity and hedge funds}

Alfred W. Jones created the first "hedged fund" in 1949 in the United States. His idea was to create an investment fund whose performance was protected (or hedged) against the general movement of the market (Lhabitant, 2007). Jones combined "long" positions (i.e. buying stocks with the expectation that their value will increase) in supposedly undervalued stocks with short-selling stocks believed to be overvalued. Additionally, he borrowed funds to amplify returns - a method widely practiced by hedge funds today, known as leverage. The fee model of hedge funds was also novel; most managers took 20 percent of the realized profits, combined with a management fee of 2 percent (known as " 2 -and-20"), which is still the prevalent structure today. 
During the 1940s, however, most people on Wall Street saw leverage and short-selling as "too racy for professionals entrusted with other people's savings" (Mallaby, 2010: 23). Thus, it is not surprising that between the 1950s and the 1990s hedge funds were largely unknown to the general public and the assets these funds had under management amounted to only a tiny fraction of the overall financial markets. They were just too small to matter - for business and for academia. To date, no universally accepted definition of hedge funds exists. In general, hedge funds are private and largely unregulated investment vehicles that primarily cater to wealthy individuals and institutional investors and are able to employ any investment strategy (Fichtner, 2013a).

During the 1980s, many hedge funds changed their investment strategies. Whereas before most actually tried to limit risks by diversifying and hedging their investments, now - after the end of Bretton Woods - many employed quite risky and speculative concentrated bets using the plethora of new financial markets and instruments, such as foreign currencies and derivatives. Hence, the term "hedge" funds increasingly became a misnomer - perhaps a more apt term since then would be "wager" or "speculation" funds (although some funds still hedge in the traditional sense). In the 1990s and 2000s, hedge funds enjoyed phenomenal growth, largely driven by an influx of capital from high net-worth individuals (ibid.). In 1990, there were about 500 hedge funds with assets of about US\$40 billion. By late 2007, this number had skyrocketed to a pre-crisis peak of about 10,000 funds managing close to US\$2,000 billion. In 2017, approximately 8,300 hedge funds had about US\$3,200 billion in assets under management.

The hedge fund industry is dispersed; there are many small funds and only few large ones. Arguably, this is because there are no significant economies of scale. Many funds even seek to limit their size, because they want to avoid that their trades affect market prices. However, at the same time the global hedge fund industry is a uniquely concentrated financial industry geographically. Hedge fund managers are almost exclusively based in New York and London, while most funds have their legal domicile in the Cayman Islands and Delaware (Fichtner, 2016; see also Harrington, 2019, and Fernandez and Hendrikse, 2019, in this volume).

Private equity funds are also often legally based in Delaware and other tax havens. Moreover, private equity funds are similar to hedge funds in the respect that they charge high fees. The major difference is that - as their name suggests - private equity funds mainly acquire listed corporations and take them off the public stock markets through so-called leveraged buy-outs (Appelbaum and Batt, 2014). Usually the debt load of the target firm is then increased substantially while dividends are paid out to the private equity fund. Froud and Williams (2007) have called this business model "value extraction" through financial engineering. Hence, the short-term financial interests of the private equity fund often dominate over the medium and long-term interests of employees, suppliers and other stakeholders in the firm. This is the way in which private equity funds contribute to the financialization of (listed) corporations. 
Hedge funds and private equity funds still only represent a small proportion of the entire global financial stock - below 3 percent each. However, because of leverage and their unique ability to concentrate assets in a few investments, hedge funds have an impact that is several times greater than this small proportion would suggest. In other words, their high agility and their capacity to place large concentrated bets enable hedge funds to influence markets much more than other investors are able to. Hedge funds are also very active investors, representing high shares of the trading in many segments of financial markets. Hence, hedge funds have become influential actors in many markets (Fichtner, 2013a).

Some hedge funds played an important role in the pumping up of the US real estate bubble that eventually triggered the global financial crisis and others initiated the bursting of that bubble. The hedge funds Magnetar and Paulson \& Co cooperated with investment banks such as Goldman Sachs to create large quantities of highly complex collateralized debt obligations (CDOs) which could be sold to unsophisticated investors that did not fully understand these opaque (and ultimately toxic) financial products. Subsequently, Magnetar and other hedge funds wagered against the very same CDOs they helped to create using another arcane financial instrument - credit default swaps (CDS) (Eisinger and Bernstein, 2010). In what has been dubbed "the greatest trade ever" Paulson \& Co made a stunning profit of about US\$15 billion in 2007 with bets on the crash of the real-estate market in the United States (Zuckerman, 2009).

One subgroup of the hedge fund industry that is crucial for the financialization of listed corporations are so-called "activist" hedge funds, which have three main features. First, activist hedge funds try to increase the market value of the targeted company. Second, they try to benefit from perceived market imbalances, such as undervalued firms. Third, in many instances activist hedge funds benefit from asset transfers at the expense of other stakeholders in the firm such as workers, suppliers or creditors (Fichtner, 2013b). Activist hedge funds typically acquire stakes of between 5 and 10 percent of the outstanding shares of a listed corporation. Then they call for measures to increase short-term shareholder value: the payment of special dividends, the launch of share buyback programs or the sale of divisions that are not judged part of the "core competency" of the company. Sometimes funds team up and form "wolf packs" to amplify their impact on target firms (Briggs, 2006).

Some large deals set important precedents and thus demonstrated the potential power of activist hedge funds over listed corporations, for example the "Deutsche Börse affair" (Watson, 2005). In this episode, a group of hedge funds bought a large stake in the leading German stock exchange operator. Subsequently they forced the firm to abandon the proposed takeover of the London Stock Exchange and instead to pay out "surplus" cash to shareholders. Another case was the two activist funds $\mathrm{TCl}$ and Atticus pushing for the record-breaking takeover of the Dutch bank ABN Amro by Royal Bank of Scotland, Fortis and Banco Santander in 2007. This risky deal later turned out to be catastrophic for Fortis and Royal Bank of Scotland 
as it was done completely in cash, which these banks had borrowed, rather than being financed by the issuance of new shares. It left them with large amounts of debt, and both banks subsequently had to be bailed out by their home countries. Activist hedge funds see companies predominantly as bundles of financial assets that can be dismembered, traded and recombined rather than as sources of production and employment, and thus have driven particularly intense forms of corporate financialization. Though still quite a small subgroup of the whole hedge fund industry, activist funds have reached a new all-time high in assets under management in 2017 (Financial Times, 2017a). Likewise, private equity funds have record levels of capital at their disposal (Financial Times, 2017b).

Hedge funds and private equity funds exert kinds of disciplinary power of listed corporations that do not have "protective" blockholders, i.e. large permanent shareholders that support long-term strategies of their investee companies (Fichtner, 2015). Because if they do not have such suppliers of "patient" capital, it would be rational for listed firms to implement some of the typical demands to maximize shareholder value in order not to become viable targets. Of course, such effects are mediated by the institutional configurations of political economies, such as ownership structures. Ownership of listed companies is different in Germany and Japan, where patient capital in the form of domestic blockholders still exists, compared to United Kingdom and the United States, which are normally seen as dominated by impatient capital. The United Kingdom and the United States are traditionally portrayed as political economies in which few listed firms have large blockholders. Instead, most firms are assumed to have dispersed ownership structures with many different institutional and private investors (the famous separation of ownership and control). However, since the global financial crisis there is a powerful ongoing trend that is fundamentally changing the ownership structures of listed firms in the United States and elsewhere - the rise of passive index funds.

\section{The low fee segment: passive index funds}

The basic premise of index funds is that historically the vast majority of actively managed mutual funds have not been able to "beat" (financially outperform) broad-based stock market indices, such as the S\&P 500 (Bogle, 2016). Yet they charge considerable fees. Hence in 1976, Vanguard created the first index mutual fund that replicated the S\&P 500 and kept costs for investors low. Index funds replicate stock indices by buying shares of the member firms of the particular index and then hold them "forever" (unless the composition of the index changes). At that time, the concept was being attacked by many on Wall Street as "un-American" because there was no attempt to beat the market. And, in fact, index funds remained a small niche for almost three decades. In the early 1990s, State Street introduced exchange traded funds (ETFs), which have in common with index mutual funds that they track stock indices and keep costs low. The main difference is that ETFs trade continuously the entire trading day, which makes them much more liquid and thus more attractive for institutional investors such as hedge funds. Index funds are much cheaper than active mutual funds, with fees of around 
0.1 percent. Lauded by some as the "democratization" of investing, these low fees have driven the enormous increase in assets under management in recent years (Novick, 2017).

During the last decade, investors have shifted capital from expensive actively managed mutual funds to cheap index mutual funds and ETFs on a massive scale. Between 2008 and 2017 investors sold holdings of active US equity mutual funds worth roughly US\$1,300 billion, while buying passively managed US equity funds to the tune of approximately US\$1,600 billion - a historically unprecedented money mass-migration within one decade of about US\$3,000 billion in the United States alone (see Figure 1).

Figure 1 Cumulative flows into index funds and out of actively managed funds (bn US\$)

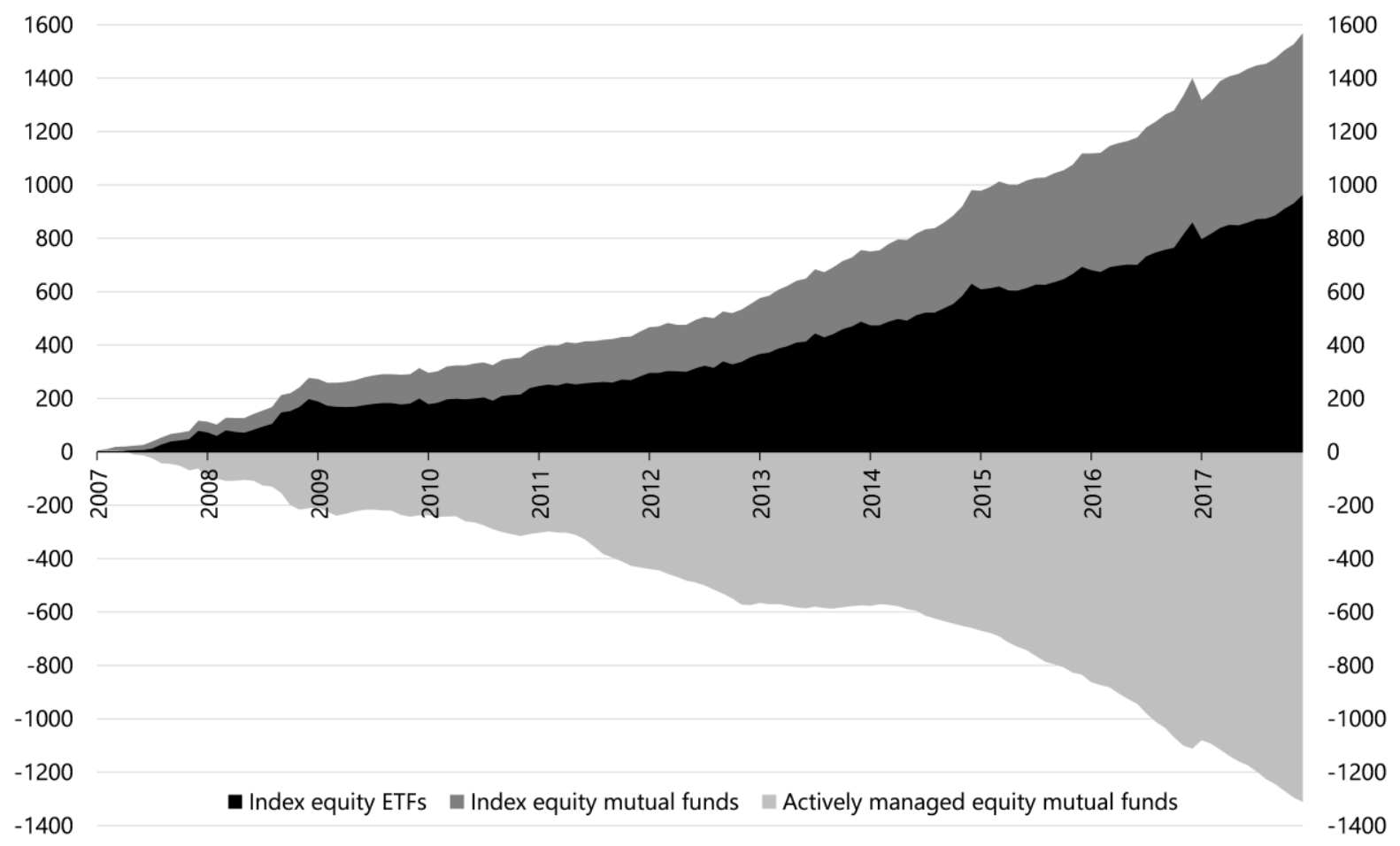

In contrast to the fragmented mutual fund industry (big players such as Fidelity notwithstanding), the large and rapidly growing index funds industry is dominated by just three American asset management firms: BlackRock, Vanguard, and State Street, which Fichtner, Heemskerk and Garcia-Bernardo (2017) consequently call the "Big Three." Together, they have well over US\$13 trillion in assets under management and control 80-90 percent of all assets in passive index funds (ibid.; WillisTowersWatson, 2017). First mover advantage and powerful economies of scale facilitate high concentration in the index fund industry and make it difficult for new competitors to take business from the incumbents. These centripetal forces make the structurally oligopolistic index fund industry markedly different from the rather centrifugally structured hedge fund and active mutual fund industries in which thousands of funds compete. Due to the enormous inflows of capital in recent years the Big Three have acquired significant shareholdings in thousands of listed corporations both in the United States and internationally. In 2015, the Big Three, seen together (as one investor block), would 
have been the largest single shareholder in 88 percent of all S\&P 500 firms, with a mean combined ownership of almost 18 percent (Fichtner, Heemskerk and Garcia-Bernardo, 2017). Thus, the rise of passive index funds is leading to a concentration of corporate ownership in the hands of the Big Three.

The exact effects of the Big Three on listed corporations are yet under-researched, however. Moreover, BlackRock, Vanguard and State Street are still in the process of adapting to their new role as the "de facto permanent governing board" of most US listed firms (Haberly and Wójcik, 2016). On the one hand, passive investors have little incentives to be concerned with firm-level governance performance, because they simply aim to replicate the performance of a group of firms while minimizing costs. On the other hand, the re-concentration of corporate ownership in the hands of the Big Three may imply a re-concentration of corporate control, since passive asset managers have the ability to exercise the voting rights of the stocks owned by their funds. Research by Fichtner, Heemskerk and Garcia-Bernardo (2017) has found that the Big Three pursue coordinated voting strategies across all of their many individual funds, which is a key precondition for effectively exerting shareholder power. Their analysis has also shown that generally BlackRock, Vanguard and State Street vote in favor of management (rather than taking activist decisions against managements) at annual general meetings.

In addition to corporate control via voting, the Big Three may exert power via two channels that are far less visible. First, they pursue private engagements with the management of companies in which they own shares to discuss issues deemed important for the particular corporation. BlackRock, for example, had almost 1,500 such private engagements from mid2015 to mid-2016 and 1,300 the year later (BlackRock, 2017). Secondly, due to the large combined ownership position of the Big Three in many listed firms, it is possible that executives of these companies would "internalize" their known objectives. This is plausible because the management of all large corporations is well-informed who the largest shareholders are and they also know the objectives of the Big Three. Moreover, management depends on the enormous voting power of BlackRock, Vanguard and State Street in proxy fights with activist investors or other shareholder conflicts. There is an emerging academic debate whether such "common ownership" (which can also involve large non-index investors) is causing affected firms active in concentrated markets, such as airlines or banks in the United States, to compete less fiercely, which could result in higher prices for consumers (Azar, Schmalz and Tecu, 2018; Schmalz, 2018). The hypothesized reason is that large common owners have the interest that all their portfolio firms maximize profits. If one of these firms lowers prices significantly to win business from its competitors, this arguably lowers profits for all of them, which would be detrimental to the interests of a common owner.

Braun (2015) has rightly argued that index funds may, in principle, act as "patient" capital that could facilitate long-term strategies of listed companies. In fact, index funds are invested "forever" in the firms that are members of a particular index and thus are in a position to potentially focus on the long-term well-being of their investee companies. For now, however, 
the actual voting behavior of BlackRock is not supporting the claim that the asset manager acts as a champion of long-termism. As argued above, two cogent proxies for short-termist and financialized behavior of listed corporations are share-buybacks as well as mergers and acquisitions. According to data from ProxyInsight for the period 2011-2017, the Big Three voted in favor of these two measures in the vast majority of cases at annual general meetings of listed firms from the United States, the United Kingdom, Japan, France and Germany. This does not necessarily mean, however, that it is impossible for the Big Three to become agents for corporate de-financialization. All three giant asset managers are currently undergoing significant transformations as they adjust to their almost public utility-like role as the dominant common owners of a continually increasing number of listed companies.

\section{Conclusion}

During the last hundred years, institutional investors have risen from being niche players to becoming large owners of an increasing number of listed corporations in many countries partly driven by the shift from "defined benefit" to "defined contribution" pension schemes. During the 1970s, individuals still held roughly 80 percent of listed corporations in the United States, while institutional investors only held 20 percent. Since then the positions have turned, individual investors now hold less than 20 percent. Different kinds of institutional investors have played key roles in different phases of their development and growth. Actively managed mutual funds (the "medium fee" segment) developed as early as the 1920 s and have remained the largest kind of institutional investor until today (measured by assets under management). Private equity and hedge funds (the "high fee" segment) grew rapidly in the 1990s and 2000s but nonetheless both are significantly smaller than mutual funds.

Arguably, private equity and (activist) hedge funds have driven the financialization of listed companies by demanding the maximization of short-term shareholder value, inter alia through special dividends and share buybacks, and more generally evaluating corporations as bundles of assets that should be split and recombined to maximize financial returns. The mantra of "downsize-and-distribute" that emerged in the 1980s has by now largely displaced the old "retain-and-reinvest" model, at least in the United States. According to Lazonick, this shift is largely responsible for many of the negative effects of financialization such as increased inequality and lower economic growth. In fact, the function of public stock markets has been completely reversed during the rise of financialization. Whereas corporations once used them to issue equity to fund investment, now the opposite happens. Since 2000, US equity markets have facilitated an extraction of capital from listed corporations to investors (i.e. primarily the top 1-10 percent) of over US\$5 trillion, thanks to share buybacks.

This chapter also discussed an ongoing momentous development within the institutional investment fund space - the rise of index funds. The burgeoning index fund industry is dominated by just three large US asset managers. Collectively, BlackRock, Vanguard and State 
Street are rapidly becoming the new dominant owners of most US listed corporations - and are expanding their reach in other countries too. Together, BlackRock, Vanguard and State Street now have assets under management that are four times as large as the entire hedge fund industry, which includes over 8,000 funds. As index fund managers the "Big Three" are invested permanently in their thousands of portfolio companies.

Therefore, in contrast to most active institutional investors that buy and sell companies frequently, they have the clear potential to become agents of corporate de-financialization and long-termism. On the one hand, the extremely broad ownership in thousands of firms means that the Big Three arguably do not have firm-specific interests but rather industry- or economy-wide interests. On the other hand, being index investors means that too risky firm behavior or very short-term strategies will eventually impact the portfolios of their retail investors in a negative way. BlackRock already claims to be a champion of long-termism. For now, their actual voting behavior is not supporting that claim, however.

Due to their enormous size and broad corporate ownership, the Big Three perform an almost public utility-like role in the United States and increasingly in other countries as well. Hence, in the next years, the public, regulators and investors of the Big Three might press for a voting behavior that is more congruent with their proclaimed long-term or "patient" corporate governance strategies. Such a transformation of the Big Three into "agents of corporate definancialization" is far from certain, of course, as they face conflicting interests between maximizing investor inflows while minimizing costs and exposure to (new) regulation. However, what is certain is that from all the institutional investors discussed in this chapter, the Big Three index investors have by far the highest potential to stop and potentially reverse the financialization of listed corporations.

Jan Fichtner is postdoctoral researcher in the CORPNET project at the University of Amsterdam. His research interests lie in the interdisciplinary field of International Political Economy, particularly Global Finance, and cover index funds, the concentration of corporate ownership and control, structural power, financialization, hedge funds, and offshore financial centers. 


\section{References}

Appelbaum, E. and Batt, R., 2014. Private Equity at Work: When Wall Street Manages Main Street. New York: Russell Sage Foundation.

Azar, J., Schmalz, M. and Tecu, I., 2018. Anti-Competitive Effects of Common Ownership. Journal of Finance, 73(4): pp.1513-1565.

Berle, A. and Means, G. C., 1932. The Modern Corporation and Private Property. New York: Macmillan.

BlackRock, 2017. Investment Stewardship Priorities 2017-2018. Available at: https://tinyurl.com/y8bgda2v [Accessed 23 Nov. 2018].

Bogle, J. C., 2016. The Index Mutual Fund: 40 Years of Growth, Change, and Challenge. Financial Analysts Journal, January/February. Available at: http://www.cfapubs.org/doi/pdf/10.2469/faj.v72.n1.5 [Accessed 23 Nov. 2018].

Braun, B., 2015. From performativity to political economy: index investing, ETFs and asset manager capitalism. New Political Economy, 21(3): pp.257-273.

Briggs, T. W., 2006. Corporate governance and the new hedge fund activism: An empirical analysis. Journal of Corporation Law, 32(4): pp.681-738.

Davis, G. F., 2008. A new finance capitalism? Mutual funds and ownership re-concentration in the United States. European Management Review, 5(1): pp.11-21.

De Jongh, M., 2011. Shareholder Activists Avant la Lettre: The "Complaining Participants" in the Dutch East India Company. In: Koppell, J., ed., Origins of Shareholder Advocacy. London: Palgrave Macmillan, pp.1622-1625.

Eisinger, J. and Bernstein, J., 2010. The Magnetar Trade: How One Hedge Fund Helped Keep the Bubble Going. Available at: https://tinyurl.com/yacdnkb2 [Accessed 23 Nov. 2018].

FactSet, 2016. Buyback Quarterly Q4-15. Available at:

https://www.factset.com/websitefiles/PDFs/buyback/buyback 3.17.16/view [Accessed 23 Nov. 2018].

Federal Reserve, 2017. Quarterly Issuance and Retirement. Available at: https://www.federalreserve.gov/releases/efa/equity-issuance-retirement-quarterly.htm [Accessed 23 Nov. 2018]. 
Fichtner, J., 2013a. The Rise of Hedge Funds: A Story of Inequality. Momentum Quarterly, 2(1): pp.3-20.

Fichtner, J., 2013b. Hedge Funds: Agents of Change for Financialization. Critical Perspectives on International Business, 9(4): pp.358-376.

Fichtner, J., 2015. Rhenish Capitalism Meets Activist Hedge Funds: Blockholders and the Impact of Impatient Capital. Competition \& Change, 19(4): pp.336-352.

Fichtner, J., 2016. The anatomy of the Cayman Islands offshore financial center: AngloAmerica, Japan, and the role of hedge funds. Review of International Political Economy, 23(6): pp.1034-1063.

Fichtner, J., Heemskerk, E. M. and Garcia-Bernardo, J., 2017. Hidden power of the Big Three? Passive index funds, re-concentration of corporate ownership, and new financial risk. Business and Politics, 19(2): pp.298-326.

Financial Times, 2017a. Activists have boardrooms singing to a new tune. 23 December, p.13.

Financial Times, 2017b. Private equity fundraising hits post-crisis high. Available at:

https://www.ft.com/content/906b2b86-828c-11e7-94e2-c5b903247afd [Accessed 23 Nov. 2018].

Froud, J. and Williams, K., 2007. Private equity and the culture of value extraction. New Political Economy, 12(3): pp.405-420.

Haberly, D. and Wójcik, D., 2016. Earth Incorporated: Centralization and Variegation in the Global Company Network. Available at: https://papers.ssrn.com/abstract=2699326 [Accessed 23 Nov. 2018].

Horn, L., 2017. The Financialization of the Corporation. In: Baars, G. and Spicer, A., eds., The Corporation: A Critical, Multi-Disciplinary Handbook. Cambridge: Cambridge University Press, pp. 281-290.

Kay, J., 2016. Other People's Money: Masters of the Universe or Servants to the People? London: Profile Books.

Lazonick, W. and O'Sullivan, M., 2000. Maximizing shareholder value: a new ideology for corporate governance. Economy \& Society, 29(1): 13-35. 
Lazonick, W., 2015. Stock buybacks: From retain-and-reinvest to downsize-and-distribute. Brookings. Available at: https://www.brookings.edu/wp-

content/uploads/2016/06/lazonick.pdf [Accessed 23 Nov. 2018].

Lhabitant, F.-S., 2007. Handbook of Hedge Funds. Chichester: Wiley.

Mallaby, S., 2010. More Money than God: Hedge Funds and the Making of a New Elite. London: Bloomsbury.

Novick, B., 2017. How Index Funds Democratize Investing. The Wall Street Journal. Available at: https://tinyurl.com/y73fyl39 [Accessed 23 Nov. 2018].

Rutterford, J. and Hannah, L., 2016. The Rise of Institutional Investors. In: Chambers, D. and Dimson, E., ed., Financial Market History: Reflections on the Past for Investors Today. New York: CFA Institute Research Foundation, p.242-263.

Schmalz, M. C., 2018. Common-Ownership Concentration and Corporate Conduct. Available at: https://ssrn.com/abstract=3046829 [Accessed 23 Nov. 2018].

Useem, M., 1996. Investor Capitalism: How Money Managers are changing the Face of Corporate America. New York: BasicBooks.

Watson, M., 2005. Hedge funds, the Deutsche Börse affair and predatory Anglo-American capitalism. The Political Quarterly, 76(4): pp.516-528.

WillisTowersWatson, 2017. The world's 500 largest asset managers - year end 2016. Available at: https://tinyurl.com/ycketcgk [Accessed 23 Nov. 2018].

Wolff, E. N., 2014. Household Wealth Trends in the United States, 1962-2013: What Happened over the Great Recession? NBER Working Paper. No. 20733.

Zuckerman, G., 2009. The Greatest Trade Ever: The Behind-the-Scenes Story of How John Paulson Defied Wall Street and Made Financial History. New York: Broadway Books. 